\title{
Removal of Esophageal Variceal Bands to Salvage Complete Esophageal Obstruction
}

\author{
Ala' A Abdel Jalil, Ghassan Hammoud, Jamal A Ibdah and Sami Samiullah \\ Division of Gastroenterology \& Hepatology, University of Missouri-Columbia, Columbia, MO, USA
}

Esophageal varices develop in almost half of the patients with cirrhosis, and variceal hemorrhage constitutes an ominous sign with an increased risk of mortality. Variceal banding is considered an effective and mostly safe measure for primary and secondary prophylaxis. Although adverse events related to banding including dysphagia, stricture formation, bleeding, and ligation-induced ulcers have been described, complete esophageal obstruction is rare, with only 10 reported cases in the literature. Among those cases, 6 were managed conservatively; 1 patient had esophageal intraluminal dissection from an attempt to remove the bands using biopsy forceps but ultimately recovered with conservative management. Three patients developed strictures following removal of the bands, requiring repeated sessions of dilation therapy. We report on a patient who developed absolute dysphagia and complete esophageal obstruction after variceal banding. We successfully used the endoloop cutter hook to release the bands intact and restore luminal integrity.

Clin Endosc 2018;51:491-494

Key Words: Band ligation; Cirrhosis; Dysphagia; Esophageal obstruction; Endoscopy

\section{INTRODUCTION}

Portal hypertension is a progressive complication of cirrhosis, and gastroesophageal varices occur in almost half of the cirrhotic patients. ${ }^{1}$ The risk of variceal hemorrhage increases with the presence of large varices ( $>5 \mathrm{~mm}$ ), a red wale sign, and alcoholic cirrhosis, and indicates the severity of liver disease. Although the risk of first variceal hemorrhage is approximately $20 \%$, the risk of rebleeding approaches $70 \%$, and secondary prophylaxis becomes an important measure to mitigate such high risk. ${ }^{2}$ Variceal hemorrhage continues to show a high mortality rate (20\% at 6-weeks) despite advances in therapeutic measures (vasoactive medications, antibiotics, and endoscopic interventions). ${ }^{3}$ Two large meta-analyses found lower rates of

Received: December 26, 2017 Revised: April 10, 2018

Accepted: April 10, 2018

Correspondence: Sami Samiullah

Division of Gastroenterology \& Hepatology, University of Missouri-Columbia, 1 Hospital Dr. CE 405, Columbia, MO 65212, USA

Tel: +1-573-884-6044, Fax: +1-573-884-4595, E-mail: samiullah@health.missouri.edu ORCID: https://orcid.org/0000-0002-1498-0527

(cc) This is an Open Access article distributed under the terms of the Creative Commons Attribution Non-Commercial License (http://creativecommons.org/ licenses/by-nc/3.0) which permits unrestricted non-commercial use, distribution, and reproduction in any medium, provided the original work is properly cited. first variceal hemorrhage with use of endoscopic variceal ligation (EVL) than with $\beta$-blockade therapy, although there was no significant difference in mortality rates. ${ }^{4,5}$ EVL carries a risk of ligation-induced ulceration in $0.5 \%-3.6 \%$ of patients. ${ }^{6}$ Complete esophageal obstruction secondary to EVL is rare, with only 10 cases described in the literature.

\section{CASE REPORT}

A 68-year-old woman with a history of diabetes mellitus, living-donor renal transplant on current immunosuppression, and compensated cirrhosis secondary to hepatitis $\mathrm{C}$ genotype 1a presented for esophageal variceal surveillance. The patient had no history of variceal bleeding, encephalopathy, or ascites. Liver function indices were unremarkable. Upon her first endoscopy, 2 large columns of varices were found with high-risk stigmata of a red wale sign, and 5 bands were applied successfully. She presented to us for her third session of surveillance and 3 additional variceal bands were applied (Fig. 1A, B; before and after banding). Immediately after the procedure the patient could not swallow any liquids or secretions, with persistent spitting up of saliva admixed with small streaks of blood. Viscous 


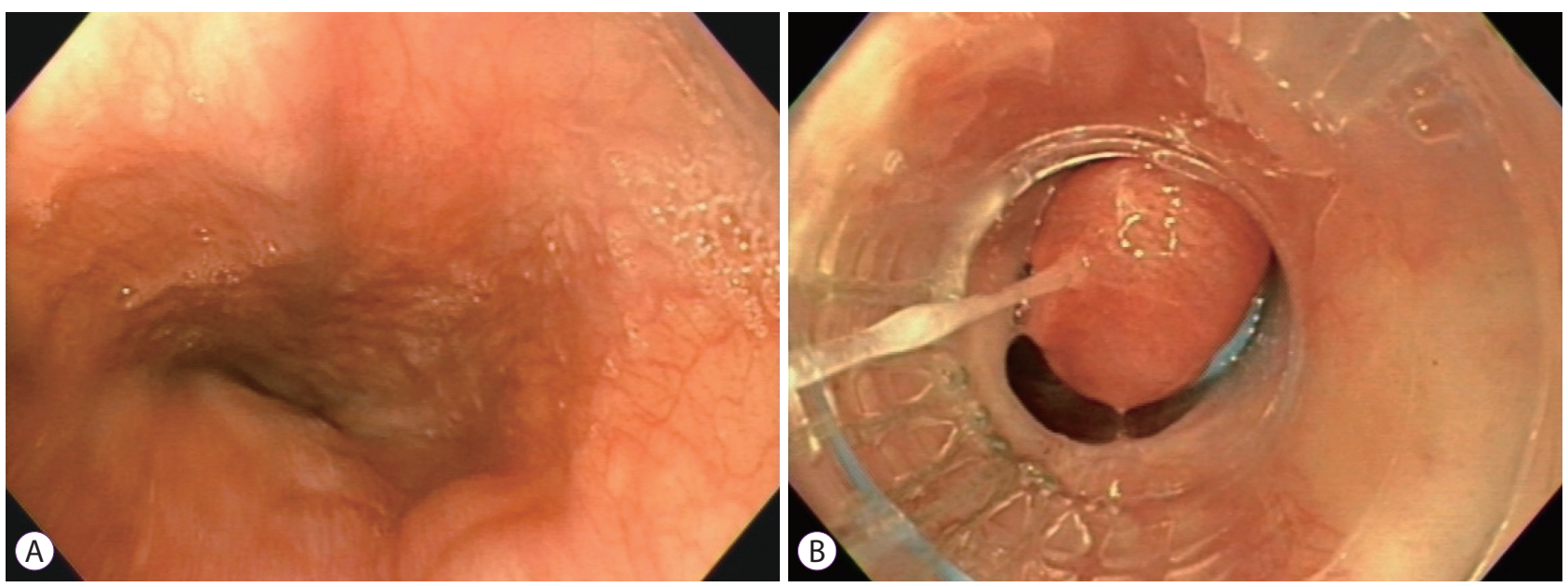

Fig. 1. (A) Pre-band ligation endoscopic image showing 2 large columns of varices in distal esophagus. (B) Post-band ligation endoscopic image.
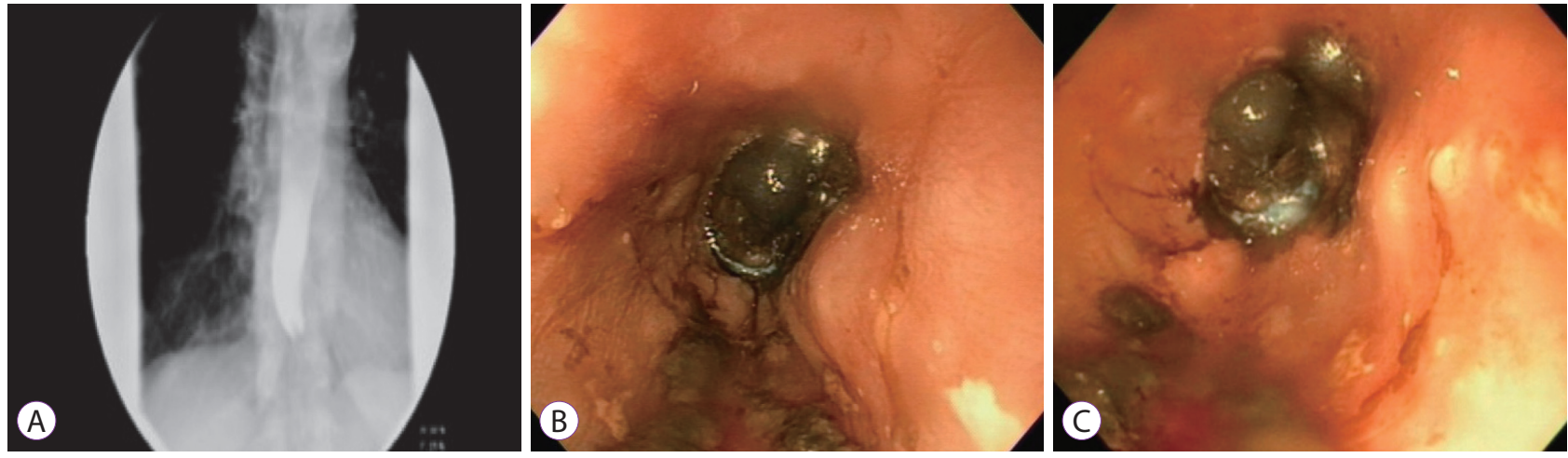

Fig. 2. (A) Barium esophagram showing complete distal esophageal obstruction. (B, C) Complete esophageal obstruction, necrotic varix with band at its base.

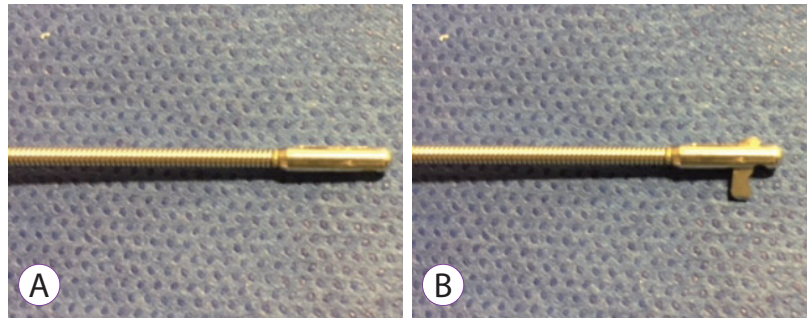

Fig. 3. (A, B) Endoloop cutter (closed \& open).

lidocaine mixed with water failed to provide any relief. The patient was admitted for observation with nothing by mouth. Sucralfate was started along with proton-pump inhibitor therapy. By the second day, the patient was still unable to swallow any liquids including her own saliva. A barium esophagram showed complete obstruction of the distal esophagus (Fig. 2A). Repeat esophagogastroduodenoscopy (EGD) the following day showed pooling of saliva in the distal esophagus, which was suctioned, along with necrotic and ulcerated esophageal mucosa at the base of the banded varices causing complete luminal obstruction (Fig. 2B, C). We grasped the 3 bands with the hook of an endoloop cutter (Olympus America, Melville, NY, USA) (Fig.

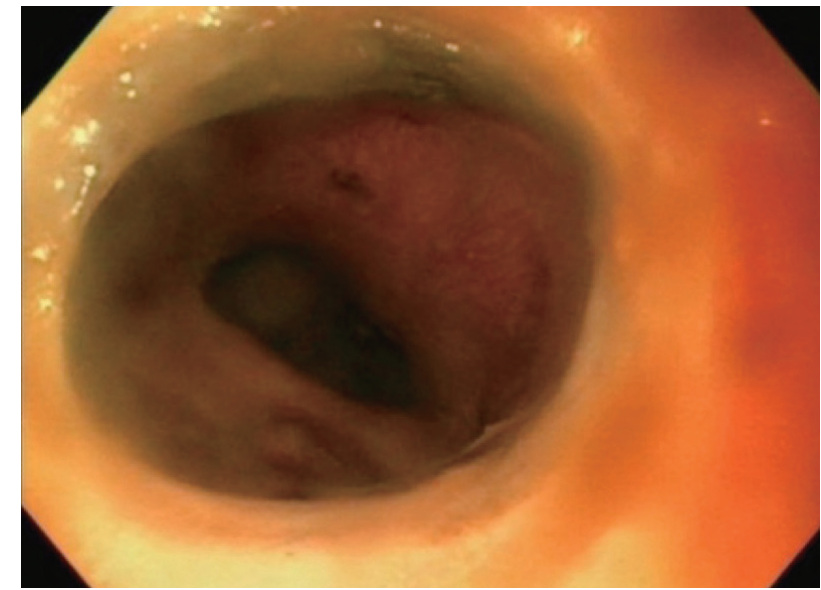

Fig. 4. Restoration of esophageal lumen after removal of variceal bands using endoloop cutter hook.

$3 \mathrm{~A}, \mathrm{~B})$, and the bands were removed intact from the base of necrotic varices one-by-one without any bleeding. This restored the esophageal lumen (Fig. 4) and led to resolution of symptoms. The patient was discharged home the following day tolerating a regular diet. Upon follow-up endoscopy, scars were seen 
in the area without any varices.

\section{DISCUSSION}

To date, 10 cases of complete esophageal obstruction following variceal banding have been described (Table 1$){ }^{7-16}$ Saltzman and Arora described the first case in 1993 in a 58-year-old man who had 2 prior sessions of sclerotherapy. ${ }^{7}$ After the second treatment with variceal banding, the patient developed sialorrhea and chest discomfort. Repeat EGD showed impact- ed food above edematous and swollen varices, with 4 bands in place. ${ }^{7}$ Elizondo-Rivera et al. reported a case in which a large nonbleeding varix was banded with over-suctioning of mucosa resulting in complete obstruction of the esophageal lumen. ${ }^{8}$ The patient had prior, banding and at the time of index endoscopy there was evidence of scarring along with mild stenosis in the distal esophagus. ${ }^{8}$ Following conservative management, Nawaz et al. managed a case in 2010 in which banding small varices resulted in complete esophageal occlusion and subsequent ulcer and stricture formation. ${ }^{9}$ In 2011, de Melo removed an occluding band successfully using a clear cap

Table 1. Published Cases of Complete Esophageal Obstruction Secondary to Endoscopic Variceal Band Ligation

\begin{tabular}{|c|c|c|c|c|}
\hline Study & Timing of symptoms & EGD & Management & Outcome \\
\hline $\begin{array}{l}\text { Mansour et al. } \\
(2017)^{16}\end{array}$ & $\begin{array}{l}3 \text { days later } \\
\text { with nausea \& vomiting. }\end{array}$ & $\begin{array}{l}\text { Complete obliteration of } \\
\text { lumen at the GEJ } \\
\text { Esophageal band with } \\
\text { inadvertent gastric tissue } \\
\text { was seen }\end{array}$ & Conservative management & $\begin{array}{l}\text { Distal esophageal stricture } \\
\text { requiring } 4 \text { sessions } \\
\text { of dilation }\end{array}$ \\
\hline $\begin{array}{l}\text { Maric et al. } \\
(2016)^{15}\end{array}$ & $\begin{array}{l}\text { Immediate nausea, } \\
\text { vomiting, sialorrhea \& } \\
\text { dysphagia }\end{array}$ & $\begin{array}{l}\text { Necrotic mucosa with luminal } \\
\text { occlusion \& retained band } \\
\text { in mid-esophagus }\end{array}$ & $\begin{array}{l}\text { Band was removed } 10 \text { days } \\
\text { later using snare technique } \\
\text { with minimal cautery } \\
\text { effect to cut the band }\end{array}$ & $\begin{array}{l}\text { Mild luminal narrowing } \\
\text { status post band removal }\end{array}$ \\
\hline $\begin{array}{l}\text { Kwiatt et al. } \\
(2016)^{11}\end{array}$ & $\begin{array}{l}\text { Inability to control } \\
\text { secretions } 2 \text { hours post } \\
\text { banding }\end{array}$ & $\begin{array}{l}\text { Complete esophageal } \\
\text { obstruction, necrotic \& } \\
\text { ulcerated tissue at banding } \\
\text { site }\end{array}$ & $\begin{array}{l}\text { Successful removal with } \\
\text { endoloop cutter }\end{array}$ & $\begin{array}{l}\text { Immediate relief of } \\
\text { obstruction }\end{array}$ \\
\hline $\begin{array}{l}\text { Elizondo-Rivera } \\
\text { et al. }(2014)^{8}\end{array}$ & $\begin{array}{l}\text { Dysphagia, chest pain \& } \\
\text { vomiting (unspecified } \\
\text { timing) }\end{array}$ & $\begin{array}{l}\text { Black mucosa at banding } \\
\text { site, complete esophageal } \\
\text { obstruction }\end{array}$ & $\begin{array}{l}\text { NPO for } 7 \text { days, liquid diet } \\
\text { for } 4 \text { days }\end{array}$ & $\begin{array}{l}\text { Tolerated regular diet after } \\
11 \text { days }\end{array}$ \\
\hline $\begin{array}{l}\text { Chahal et al. } \\
(2013)^{12}\end{array}$ & $\begin{array}{l}\text { Immediate nausea, } \\
\text { vomiting \& dysphagia }\end{array}$ & $\begin{array}{l}\text { Occluded esophageal lumen } \\
\text { with entrapped varix } \\
\text { with surrounding necrosis }\end{array}$ & $\begin{array}{l}\text { Attempt to remove band } \\
\text { with biopsy forceps failed } \\
\text { and complicated by } \\
\text { esophageal intraluminal } \\
\text { dissection }\end{array}$ & $\begin{array}{l}\text { TPN for } 5 \text { days } \\
\text { Repeat EGD concluded } \\
\text { resolution of dissection }\end{array}$ \\
\hline $\begin{array}{l}\text { de Melo } \\
(2011)^{10}\end{array}$ & $\begin{array}{l}\text { Immediate inability to } \\
\text { swallow water }\end{array}$ & $\begin{array}{l}\text { Complete esophageal } \\
\text { obstruction with subsequent } \\
\text { stricture formation }\end{array}$ & $\begin{array}{l}\text { Attempts to remove occluding } \\
\text { band using forceps \& snare } \\
\text { were unsuccessful } \\
\text { Cap-assisted technique } \\
\text { (can opener maneuver) } \\
\text { dislodged the band }\end{array}$ & $\begin{array}{l}\text { Stricture requiring } 2 \\
\text { sessions of TTS dilation }\end{array}$ \\
\hline $\begin{array}{l}\text { Nikoloff et al. } \\
(2011)^{14}\end{array}$ & $\begin{array}{l}\text { Immediate chest pain, } \\
\text { dysphagia \& sialorrhea }\end{array}$ & Not repeated & TPN for 1 week & $\begin{array}{l}\text { Tolerated soft diet after } \\
7 \text { days }\end{array}$ \\
\hline $\begin{array}{l}\text { Nawaz et al. } \\
(2010)^{9}\end{array}$ & Complete occlusion & Not repeated & NS & Stricture formation \\
\hline $\begin{array}{l}\text { Verma et al. } \\
(2009)^{13}\end{array}$ & $\begin{array}{l}1 \text { day of chest pain \& } \\
\text { inability to tolerate oral } \\
\text { liquids }\end{array}$ & $\begin{array}{l}\text { Obstructing necrotic } \\
\text { varices with } 3 \text { bands at the } \\
\text { periphery }\end{array}$ & TPN for 2 weeks & No complications \\
\hline $\begin{array}{l}\text { Saltzman et al. } \\
(1993)^{7}\end{array}$ & $\begin{array}{l}\text { Immediate chest pain \& } \\
\text { sialorrhea }\end{array}$ & $\begin{array}{l}\text { Food impacted proximal } \\
\text { to variceal bandings }\end{array}$ & NS & NS \\
\hline
\end{tabular}

EGD, esophagogastroduodenoscopy; GEJ, gastroesophageal junction; NPO, nil per os; TPN, total parenteral nutrition; TTS, through the scope; NS, not specified. 
fitted to the gastroscope with a "can opener" maneuver, after unsuccessful attempts with snare and biopsy forceps. ${ }^{10}$

Kwiatt et al. described successful removal of a variceal band that caused complete esophageal obstruction. ${ }^{11}$ After unsuccessful attempts with rat-tooth and hot biopsy forceps, the variceal band was released using an endoloop cutter to grasp the band, with immediate restoration of a patent esophageal lumen. Suctioning of the opposite esophageal walls was thought to be the cause of obstruction in this case. ${ }^{11}$ A prior case of esophageal obstruction after variceal banding was complicated by intraluminal dissection in which an attempt to remove the variceal band with biopsy forceps was unsuccessful. The patient recovered with conservative management and parenteral nutrition for 5 days. ${ }^{12}$ Two other cases managed conservatively with parenteral nutrition for 1-2 weeks had resolution of symptoms. ${ }^{13,14} \mathrm{Re}-$ cently, a 79-year-old female with nonalcoholic steatohepatitis cirrhosis who developed acute onset of dysphagia after variceal banding was successfully managed 10 days later, using a $1.5-\mathrm{cm}$ snare technique along with blended cutting current to remove the occlusive band. The patient developed mild stricture afterward, but the obstruction was relieved. ${ }^{15}$ Mansour et al. described a patient with alcoholic cirrhosis and sliding hiatal hernia, who had a portion of the gastric mucosa inadvertently entrapped within the band, resulting in complete esophageal obstruction. ${ }^{16}$ That was treated conservatively, but resulted in distal esophageal stricture requiring multiple sessions of dilation therapy. ${ }^{16}$

Dysphagia following EVL can present late as a result of stricture formation, or early because of altered esophageal motility. ${ }^{17}$ Complete esophageal obstruction can occur when the mucosa is over-suctioned, especially on opposing walls. In addition, propagation of banded varices by peristaltic effect toward a more distal stricture (Schatzki ring or stricture from prior banding) is another potential mechanism for complete esophageal obstruction after banding.

We believe the preferred method is to remove the bands, to allow prompt restoration of the lumen and alleviate symptoms of pain and obstruction. Leaving the bands could carry potential risks of post-banding ulcers, bleeding, or future stricture formation. However, removing the bands using an endoloop hook cutter is an easy and safe procedure to perform and alleviates further pain.

The endoloop hook cutter is introduced in the working channel of the endoscope. The assistant opens the hook cutter and the endoscopist maneuvers the endoscope so the band hooks onto the endoloop hook cutter. The endoscope is then advanced gently and by turning the large wheel upward, the band is lifted away. We recommend against cutting the band due to risk of accidental injury to the mucosa or nearby varices.

Prompt evaluation of patients who develop symptoms con- cerning for esophageal obstruction after variceal band ligation is essential for timely management of this rare complication. In experienced hands, removal of variceal bands using an endoloop cutter hook is useful to promptly salvage the obstruction. Our case is the second to show successful removal of occluding bands using an endoloop cutter. This can avoid prolonged symptoms, hospital stays, and need for parenteral nutrition.

\section{Conflicts of Interest}

The authors have no financial conflicts of interest.

\section{REFERENCES}

1. Garcia-Tsao G, Sanyal AJ, Grace ND, Carey W. Prevention and management of gastroesophageal varices and variceal hemorrhage in cirrhosis. Hepatology 2007;46:922-938.

2. Merli M, Nicolini G, Angeloni S, et al. Incidence and natural history of small esophageal varices in cirrhotic patients. J Hepatol 2003;38:266-272.

3. D’Amico G, De Franchis R. Upper digestive bleeding in cirrhosis. Post-therapeutic outcome and prognostic indicators. Hepatology 2003;38:599-612.

4. Khuroo MS, Khuroo NS, Farahat KL, Khuroo YS, Sofi AA, Dahab ST. Meta-analysis: endoscopic variceal ligation for primary prophylaxis of oesophageal variceal bleeding. Aliment Pharmacol Ther 2005;21:347-361.

5. Gluud LL, Krag A. Banding ligation versus beta-blockers for primary prevention in oesophageal varices in adults. Cochrane Database Syst Rev 2012:CD004544.

6. Petrasch F, Grothaus J, Mössner J, Schiefke I, Hoffmeister A. Differences in bleeding behavior after endoscopic band ligation: a retrospective analysis. BMC Gastroenterol 2010;10:5.

7. Saltzman JR, Arora S. Complications of esophageal variceal band ligation. Gastrointest Endosc 1993;39:185-186.

8. Elizondo-Rivera RL, González-González JA, Garcia-Compean D, Maldonado-Garza HJ. Complete esophageal obstruction after endoscopic variceal band ligation. Endoscopy 2014;46 Suppl 1 UCTN:E457-E458.

9. Nawaz A, Sarwar S, Batul A. Complete esophageal occlusion following esophageal variceal band ligation: an unusual complication: a case report. Visible Human Journal of Endoscopy 2010;9:1-4.

10. de Melo SW. Complete esophageal occlusion after band ligation. Endoscopy 2011;43 Suppl 2 UCTN:E259.

11. Kwiatt JT, Merchant P. Successful removal of an esophageal band causing complete esophageal obstruction after variceal ligation. Gastrointest Endosc 2016;83:1030-1031.

12. Chahal H, Ahmed A, Sexton C, Bhatia A. Complete esophageal obstruction following endoscopic variceal band ligation. J Community Hosp Intern Med Perspect 2013;3.

13. Verma D, Pham C, Madan A. Complete esophageal obstruction: an ususual complication of esophageal variceal ligation. Endoscopy 2009;41 Suppl 2:E200-E201.

14. Nikoloff MA, Riley TR 3rd, Schreibman IR. Complete esophageal obstruction following endoscopic variceal ligation. Gastroenterol Hepatol (N Y) 2011;7:557-559.

15. Maric L, Alonso Y, Alvarez A, Erim T. Endoscopic variceal band ligation leading to acute onset dysphagia. Am J Gastroenterol 2016;111:S692.

16. Mansour M, Abdel-Aziz Y, Awadh H, Shah N, Ajmera A. Complete esophageal obstruction after endoscopic variceal band ligation in a patient with a sliding hiatal hernia. ACG Case Rep J 2017;4:e8.

17. Goff JS, Reveille RM, Van Stiegmann G. Endoscopic sclerotherapy versus endoscopic variceal ligation: esophageal symptoms, complications, and motility. Am J Gastroenterol 1988;83:1240-1244. 